\title{
Retinoid-related orphan nuclear receptor alpha (RORa)-deficient mice display morphological testicular defects
}

\author{
Ramy K. A. Sayed ${ }^{1,2} \cdot$ Doaa M. Mokhtar $\mathbb{1}^{3}$ - Marisol Fernández-Ortiz ${ }^{1,4} \cdot$ Germaine Escames $^{1,4,5}$ • \\ Darío Acuña-Castroviejo $\mathbb{B}^{1,4,5}$
}

Received: 21 March 2019 / Revised: 22 May 2019 / Accepted: 17 June 2019 / Published online: 13 August 2019

(c) United States \& Canadian Academy of Pathology 2019

\begin{abstract}
The role of retinoid-related orphan receptor, one of the transcription factors reported in testis, in testicular function is unclear, so this study was performed to evaluate the qualitative and quantitative changes in the testicular structure of ROR $\alpha$-deficient mice using light-, electron-microscopy, and immunohistochemistry. Among the most striking alterations observed in the testis of the mutant mice were hypospermatogenesis, marked reduction in volume proportions of interstitial tissues and number of Leydig cells, significant decrease in the diameter of seminiferous tubules and height of their epithelium, vacuolation in the epithelium of the seminiferous tubules with occurrence of mast cells, appearance of delay spermiation signs, and changes in sperm morphology. Moreover, the testis of mutant mice showed symplasts, in addition to appearance of multinucleated giant bromophenol-positive cells. ATPase activity was limited to spermatogonia and some primary spermatocytes, with higher alkaline phosphatase expression. Stronger vimentin reaction was immunolocalized to spermatogonia, spermatids, Leydig cells, and Sertoli cells. The expression of CD117 (C-kit, stem cell growth factor receptor) was limited to spermatogonia, primary spermatocytes, and Leydig cells. Seminiferous tubules showed overexpression of vascular endothelial growth factor (VEGF). Transmission electron microscopy examination of the mutant mice revealed abnormal Sertoli cells, hypertrophied spermatogonia, spermatocytes with degenerated mitochondria, and incompletely developed sperms. In conclusion, ROR $\alpha$ is one of the essential proteins that regulate testicular structure.
\end{abstract}

These authors contributed equally: Ramy K. A. Sayed, Doaa M. Mokhtar

Ramy K. A. Sayed

ramy.kamal@vet.sohag.edu.eg

$\bowtie$ Darío Acuña-Castroviejo

dacuna@ugr.es

1 Instituto de Biotecnología, Centro de Investigación Biomédica, Parque Tecnológico de Ciencias de la Salud, Universidad de Granada, 18016 Granada, Spain

2 Department of Anatomy and Embryology, Faculty of Veterinary Medicine, Sohag University, Sohag 82524, Egypt

3 Department of Anatomy and Histology, Faculty of Veterinary Medicine, Assiut University, Assiut 71526, Egypt

4 Departamento de Fisiología, Facultad de Medicina, Universidad de Granada, 18016 Granada, Spain

5 CIBER de Fragilidad y Envejecimiento, Ibs. Granada, Unidad de Gestión Clínica de Laboratorios Clínicos, Complejo Hospitalario de Granada, 18016 Granada, Spain

\section{Introduction}

Orphan receptors include members of the retinoidrelated orphan receptor (ROR) subfamily, comprising ROR $\alpha, \operatorname{ROR} \beta$, and ROR $\gamma$, which are also referred to as RORA, RORB, and RORC or NR1F1-3, respectively. These receptors have been cloned from different mammalian species $[1,2]$, and they are related to the regulation of multiple biological processes [3, 4]. Four ROR $\alpha$ isoforms, have been identified in humans, and only two of them, ROR $\alpha 1$ and $\mathrm{ROR} \alpha 4$, have been reported in mouse [5].

ROR family of nuclear orphan receptors is crucial transcription factors, which regulate various biological processes including lymphocyte differentiation [4], inflammation [6], lipid homeostasis [7], and circardian rhythms [8]. These receptors also have critical roles in development and cellular metabolism [9]. The functional ROR $\alpha$ transcription factor is important for the initiation of the innate immune response against inflammation [10]. 
These data led to consider RORs nuclear receptors as targets for drug discovery [11].

Among other tissues, ROR $\alpha$ nuclear receptors are expressed in testis, and some reports point to a relationship between ROR $\alpha$ and Sertoli cells function, because ROR $\alpha$ knockdown reduced sperm count in rats [12]. Recently, the expression of $\mathrm{ROR} \alpha$ as well as melatonin membrane receptors were detected in the Leydig cells isolated from goat [13] and sheep [14] testes. These reports suggested that $\mathrm{ROR} \alpha$ plays a crucial role in stimulating melatoninregulated GATA-4 transcription and steroid hormone synthesis in the spermatogonial stem cell differentiation culture system, promoting testosterone secretion from Leydig cells through ROR $\alpha$ signaling.

The adult mammalian testicles have two major physiological functions, spermatozoa production through spermatogenesis, and testosterone production through steroidogenesis [15]. The somatic cells of the testis, Sertoli cells are essential for testis formation and spermatogenesis, as these cells facilitate the germ cells progression to spermatozoa within the seminiferous tubules [16]. Testosterone secreted by Leydig cells diffuses under the luteinizing hormone stimulus into seminiferous tubules and induces spermatogenesis [17]. Telocytes (TCs) are a novel type of interstitial cells, which were previously called interstitial cells of Cajal, and may be involved in the intercellular signaling [18]. These cells are recently described in the connective tissue stroma of many organs including those of the male genital system, such as vas deferens [19], prostate [20], and seminal vesicle [21].

To analyze the actions of ROR $\alpha$ in the testis, we used the stagger mouse, an ROR $\alpha$-deficient mouse caused by a single recessive gene encoding for ROR $\alpha$ located on chromosome 9 [22]. We considered it worthwhile to evaluate the qualitative and quantitative changes in the testicular structure of ROR $\alpha$-deficient mice using light- and electronmicroscopy, and immunohistochemistry to discover the functions of this nuclear receptor on testicular function.

\section{Materials and methods}

\section{Animals}

Wild-type (WT) C57BL/6 and heterozygous B6.C3 (Cg)$\mathrm{RORa}^{\mathrm{sg} / \mathrm{J}}(\mathrm{RORa}+/ \mathrm{sg})$ mice were purchased from Jackson Laboratory (Bar Harbor, ME, USA). Heterozygotes crossed to obtain homozygous stagger mice $\left(\mathrm{RORa}^{\mathrm{sg} / \mathrm{sg}}\right)$. Mice were used at 10-12 weeks of age, and they were housed at summer season in a specific pathogen-free barrier zone at University of Granada's facility, under 12:12-h light-dark cycle (lights on at $08: 00 \mathrm{~h}$ ), and at $22 \pm 1{ }^{\circ} \mathrm{C}$. The animals had unlimited access to water and rodent chow.
All experiments were conducted in accordance with the Ethical Committee of Granada's University, the Spanish law for animal experimentation (R.D. 53/2013), the European Convention for the Protection of Vertebrate Animals Used for Experimental and Other Scientific Purposes (CETS \#123), and the National Institutes of Health Guide for the Care and Use of Laboratory Animals (National Research Council, National Academy of Sciences, Bethesda, MD, USA).

\section{Histological examination}

Control and mutant mice were anesthetized by intraperitoneal injection of equithesin $(1 \mathrm{ml} / \mathrm{kg})$, and then were transcardially perfused with warm saline followed by a solution of freshly prepared trump's fixative $(3.7 \%$ formaldehyde plus $1 \%$ glutaraldehyde in saline buffer). The testis was removed after dissection of excessive connective tissue. Samples for histological technique were collected from testis of both control and mutant mice, dissected at $1 \times$ $1 \times 0.5 \mathrm{~cm}$ and were immediately fixed in Bouin's fluid for $22 \mathrm{~h}$. The fixed materials were dehydrated in an ascending series of ethanol, cleared in methyl benzoate and then embedded in paraffin wax. Serial transverse and longitudinal paraffin sections at $5-8 \mu \mathrm{m}$ in thickness were cut using a Richert Leica Microtome (RM 2125, Germany) and stained with Harris hematoxylin and eosin [23], and Crossmon's trichrome [24]. The stained sections were examined using a Letiz Dialux 20 Microscope, and the photos were acquired by a Canon digital camera (Candison Powershot A95).

\section{Histochemical analysis and enzyme histochemistry}

For carbohydrate histochemistry, representative sections were stained by periodic acid-Schiff (PAS) technique [25]. In addition, some sections were stained for protein content by bromophenol blue [26]. ATPase activity was detected at $\mathrm{pH} 4.2$ [27], and alkaline phosphatase activity by the Gomori calcium method [28].

\section{Immunofluorescent detection of apoptotic nuclei}

For nuclear apoptosis detection, 4- $\mu$ m-thick paraffin sections were dewaxed in xylene, rehydrated in a descending series of ethanol, and washed with distilled water. The sections were air-dried and rinsed in PBS $1 \times(2 \times 5 \mathrm{~min})$ and stained with 33258 Hoechst dye (H6024, SigmaAldrich, Spain) for $1 \mathrm{~h}$. Following staining, the sections were washed in PBS $1 \times(5 \times 5 \mathrm{~min})$, air-dried, mounted, examined with LEICA DM5500B fluorescent microscope. Using Hoechst fluorescent dye facilitates demonstration of the apoptotic nuclei through penetration of the nucleus and 
Fig. 1 Morphological structure of testis of control and mutant mice. a, b The interstitial tissue of WT mice (IT, arrowhead) was found between the seminiferous tubules (ST) and contained Leydig cells and blood vessels. c In WT, the seminiferous tubules showed normal spermatogenesis with a normal arrangement of cellular types (boxed areas). d Mutant mice show marked reduction in the amount of interstitial tissue (IT) and reduction in the diameter of seminiferous tubules (ST). e Accumulation of dead spermatocytes in the lumen of seminiferous tubules of the mutant group (arrowhead). f An evident loss of arrangement of spermatogenic cells in the mutant mice with presence of pyknotic nuclei (boxed areas)
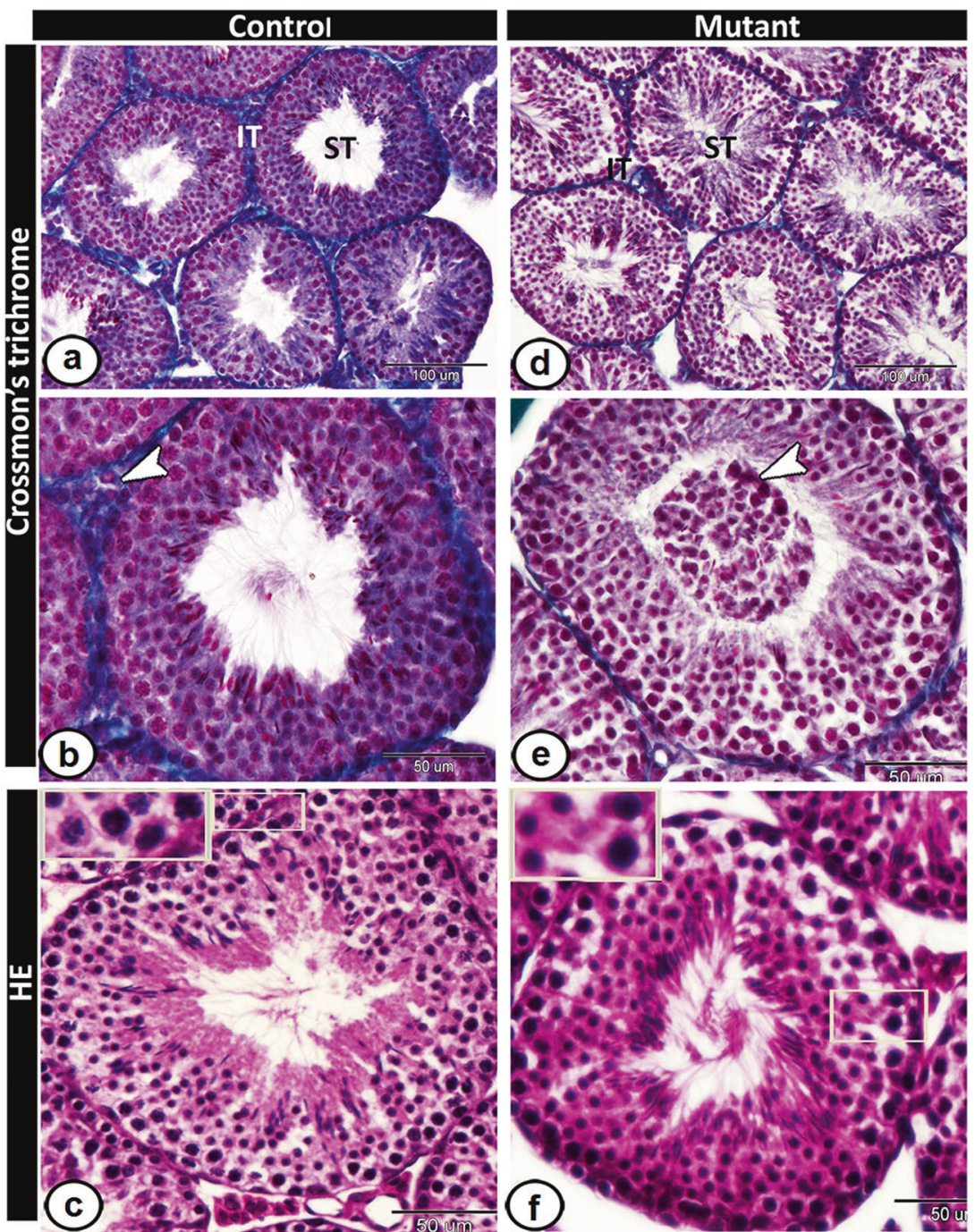

binding to DNA. Under a 350-nm wavelength light, the dye emits blue fluorescent light making the nuclear DNA visible, and consequently any chromatin condensation or nuclear fragmentation can be observed [29].

\section{Semithin sections and TEM preparations}

Small specimens of the testis of both groups were preserved by immersion in a mixture of $3 \%$ paraformaldehyde-glutaraldehyde fixative and left overnight [30]. After fixation, the samples were washed in $0.1 \mathrm{M}$ phosphate buffer and osmicated in $1 \%$ osmium tetroxide in $0.1 \mathrm{M}$ sodium cacodylate buffer at $\mathrm{pH}$ 7.3. After that, the samples were dehydrated in a graded series of ethanol followed by propylene oxide and embedded in Araldite.

Semithin sections were cut at $1-\mu \mathrm{m}$ thickness with Richert Ultracuts (Leica, Germany) and stained with toluidine blue for light microscopy. Ultrathin sections were done with Ultrotom VRV (LKB Bromma, Germany). The sections $(70 \mathrm{~nm})$ were stained with uranyl acetate and lead citrate [31] and examined by JEOL 100CX II transmission electron microscope at the Electron Microscopy Unit of Assiut University, Egypt.

\section{Digital colored images}

To increase the visual contrast between several structures on the same electron micrograph, we digitally colored specific elements (Leydig cells, TCs, etc.) to make them more visible to the reader. All the elements were carefully hand colored using Adobe Photoshop software version 6.

\section{Immunohistochemistry}

Sections of testes of both control and mutant mice were prepared for immunohistochemical analysis, they were 
deparaffinized with xylene and rehydrated in graded ethanol before being washed with twice-distilled water. To increase epitope exposure, the sections were heated for $15 \mathrm{~min}$ in sodium citrate buffer $(0.01 \mathrm{M}, \mathrm{pH} 6.0)$ in a microwave oven. The sections were cooled, washed with PBS, and then blocked with $10 \%$ bovine serum albumin (BSA) in TBST (20 mM Tris-buffered saline, $0.05 \%$ Tween 20, pH 7.5) for $1 \mathrm{~h}$ at room temperature. The sections were incubated overnight at $4{ }^{\circ} \mathrm{C}$ with diluted (1:400) polyclonal antibodies against vimentin, CD117 (C-kit, stem cell growth factor receptor), caspase-3, and vascular endothelial growth factor (VEGF). The antibodies were visualized with an SABC Kit Elite and $0.05 \%$ 3, 3-diaminobenzidine tetrachloride (Sigma) in PBS, containing $0.01 \% \mathrm{H}_{2} \mathrm{O}_{2}$ for $2 \mathrm{~min}$. The sections were counterstained with hematoxylin and mounted with cover slips. Antibody specificity was examined with the use of $1 \%$ BSA instead of primary antibody.

\section{Morphometrical and statistical analysis}

The morphometrical studies were performed on the histological sections and TEM images of the testis of both control and mutant mice using Leica Q 500MC image analyzer (Leica, Germany). They were performed by two operators, in a double-blind operation, comparing the results obtained subsequently. The measurements were carried out on 15 randomly selected sections of each testis per animal (five different areas were measured from each section) as follows:

The diameter of seminiferous tubules $(\mu \mathrm{m})$ using $\times 20$ objective.

Volume proportions of interstitial tissues (\%) using $\times 10$ objective.

The height of epithelium of seminiferous tubules $(\mu \mathrm{m})$ using $\times 100$ objective.

Number of Leydig cells per $50 \mu \mathrm{m}^{2}$ using $\times 100$ objective The number of TCs per $50 \mu \mathrm{m}^{2}$ using $\times 100$ objective.

The length of telopodes (Tps) $(\mu \mathrm{m})$ of TCs in TEM images.

All the data are presented as the means \pm SEM. For comparisons, Student's $t$ test was used (Graph Pad Prism software, San Diego, CA, USA). Differences were considered statistically significant when $P<0.05$.

\section{Results}

\section{Alteration of testicular architecture in RORa- deficient mice}

The seminiferous tubules of the WT mice showed normal spermatogenesis, and the interstitial tissue was found
Table 1 Morphometrical analysis of testicular structures in control and mutant mice

\begin{tabular}{lcr}
\hline Item & Control mice & Mutant mice \\
\hline $\begin{array}{l}\text { Diameter of seminiferous } \\
\text { tubules }(\mu \mathrm{m})\end{array}$ & $178.5 \pm 4.33$ & $151.2 \pm 5.05^{* * *}$ \\
$\begin{array}{l}\text { Volume proportions of interstitial } \\
\text { tissues }(\%)\end{array}$ & $51.9 \pm 3.61$ & $40.2 \pm 1.6^{*}$ \\
$\begin{array}{l}\text { Height of seminiferous tubules } \\
\text { epithelium }(\mu \mathrm{m})\end{array}$ & $56.58 \pm 2.01$ & $45.37 \pm 1.55^{* *}$ \\
$\begin{array}{l}\text { Number of Leydig cells per } 50 \mu \mathrm{m}^{2} \\
\text { Number of telocytes per } 50 \mu \mathrm{m}^{2}\end{array}$ & $5.75 \pm 0.75$ & $2.75 \pm 0.48^{*}$ \\
Length of telopodes $(\mu \mathrm{m})$ & $3.75 \pm 0.48$ & $2 \pm 0.41^{*}$ \\
\hline
\end{tabular}

$* p<0.05$ and $* * p<0.01$ vs. control mice

between the seminiferous compartments, containing Leydig cells and blood vessels (Fig. 1a-c). The testis of ROR $\alpha-$ deficient mice demonstrated hypospermatogenesis, marked reduction in volume proportions of interstitial tissues and number of Leydig cells, significant decrease in the diameter of seminiferous tubules, and the height of their epithelium (Fig. 1d, e, and Table 1), accumulation of degenerated spermatocytes in the lumen of the seminiferous tubules (Fig. 1e), and loss of arrangement of germ cells with presence of pyknotic nuclei (Fig. 1f).

The wall of the seminiferous tubules in the control mice was formed of 5-7 germinal epithelium layers, and the Sertoli cells contained oval nuclei with distinct deeply stained nucleoli. Normal spermatogenesis with active release of developing spermatids was observed (Fig. 2a, b). However, the germinal epithelium in the mutant animals was formed of 4-5 layers, and the germ cells showed pyknosis as well as ill-distinct cellular borders. A hypertrophied-Sertoli cell with large nucleus contained rodlike chromatin was observed (Fig. 2c). The seminiferous tubules of the mutants showed the presence of many epithelial vacuoles and engulfment of spermatid heads by Sertoli cells, resulting in localization of a few number of spermatid heads in the luminal surface of the tubules (Fig. 2d).

The spermatogonia of the WT mice were characterized by their large nuclei containing coarse chromatins, which were frequently observed in association with large primary spermatocytes that showed meiotic figures (Fig. 3a). Active spermiation was evident in the control group in form of the detachment of elongated spermatids from the apical borders of Sertoli cells leaving residual lobes from the released spermatids (Fig. 3b). The mature sperms release with their flagella into the lumen of seminiferous tubules (Fig. 3c). In ROR $\alpha$-deficient mice, changes in the appearance of germ cells, including an occurrence of mast cells localized near the basement membrane among the primary spermatocytes, were recorded (Fig. 3d). The mutant mice were 


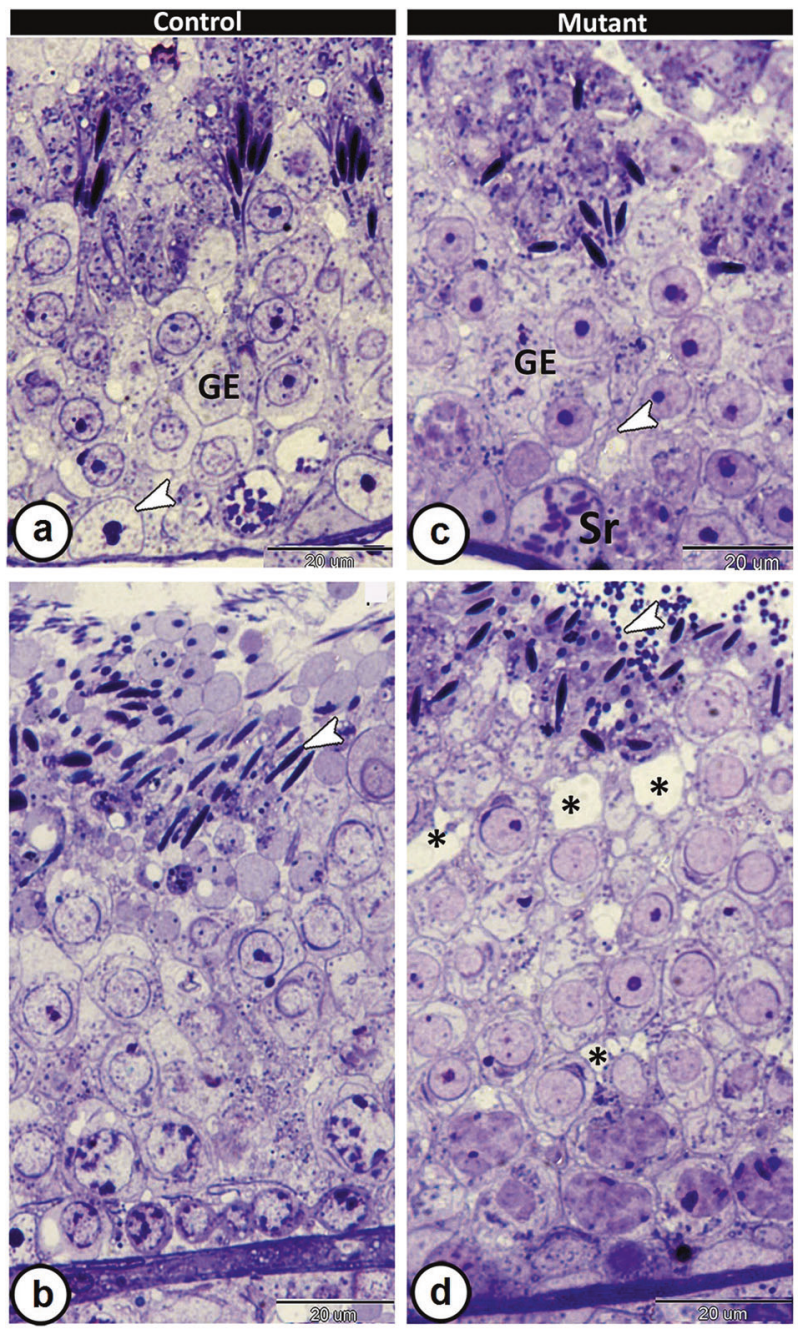

Fig. 2 Semithin sections of the wall of seminiferous tubules of control and mutant mice stained with toluidine blue. a In WT, the germinal epithelium (GE) is formed of 5-7 layers. Sertoli cells (arrowhead) contained oval nuclei with distinct deeply stained nucleoli. b Normal spermatogenesis with active released of developing spermatids (arrowhead) was shown in WT animals. $\mathbf{c}$ In mutant mice, the germinal epithelium (GE) is formed of 4-5 layers, the germ cells showed pyknosis, ill-distinct cellular borders. The Sertoli cell ( $\mathrm{Sr}$, arrowhead) is hypertrophied with a large nucleus contains rod-like chromatin. d Presence of vacuoles (asterisks) in the epithelium of seminiferous tubules of mutant mice and the Sertoli cells engulfed the spermatids heads (arrowhead)

characterized by the appearance of delay spermiation signs in form of retention of numerous spermatids deeper in the epithelium (Fig. 3e). Irregularities in the basement membrane of seminiferous tubules and changes in sperm morphology were the typical features of the mutant mice (Fig. 3f). The mast cells were also observed in the interstitial tissues of the mutant mice and displayed a characteristic metachromatic reaction by toluidine blue (Fig. 3g). Moreover, the mast cells in the seminiferous tubules showed positive immunoreactivity for their specific marker, c-kit (Fig. 3h, i).
In the control group, the seminiferous tubules were surrounded by a single layer of flattened to spindle peritubular myoid cells with flattened nuclei. The interstitial tissues were composed of Leydig cells, lymphocytes, and macrophages (Fig. 4a). TCs were a component of the interstitial tissues that exhibited a spindle-shape with oval nucleus, distributed around the tubules and blood vessels (Fig. 4b, c). Interstitial tissues of mutant mice showed many lymphatic spaces, fibroblasts. Leydig cells possessed many vacuoles and lipid droplets (Fig. 4d, e). Few TCs and pale large macrophages with many metachromatic inclusions and large vacuole were encountered in interstitial tissues of mutant mice (Fig. 4f).

\section{Histochemical testicular changes in RORa-deficient mice}

The histochemical analysis showed that the Leydig cells, the basement membrane of seminiferous tubules, and elongated spermatids attached to the apical borders of Sertoli cell in the testis of WT mice displayed PASpositive reaction. (Fig. 5a). Testis of ROR $\alpha$-deficient mice demonstrated stronger PAS-reaction in the tubules and interstitial tissues and appearance of symplasts that constituted by collapsed spermatids (Fig. 5b). The Leydig cells of WT mice showed a strong positive reaction to bromophenol blue (Fig. 5c). This reaction, however, decreases in the mutant mice with appearance of multinucleated giant bromophenol-positive cells formed by the fusion of rounded spermatids near the lumen of the seminiferous tubules (Fig. 5d).

The enzyme histochemistry in the control group revealed high ATPase activity in all spermatogenic cells. In addition, a strong staining pattern was localized in the apical borders of Sertoli cells with their associated elongated spermatids (Fig. 5e), while its activity was limited to spermatogonia and some primary spermatocytes in mutant mice. The elongated spermatids showed weak-ATPase reaction (Fig. 5f). The expression of alkaline phosphatase was strong in mutant mice compared with WT (Fig. 5g, h).

\section{Immunohistochemical and immunofluorescent testicular characteristics of RORa-deficient mice}

CD117 or C-kit expression, stem cell growth factor receptor, was stronger in spermatogonia and interstitial cells of WT mice (Fig. 6a), while its expression was limited to spermatogonia, primary spermatocytes, and Leydig cells in mutant mice (Fig. 6b). In the control group, vimentin immunolocalized to the cytoplasm of spermatogonia, elongated spermatids, and Leydig cells (Fig. 6c), while stronger reaction in the same cells of the mutant mice and a strong staining pattern in the Sertoli 
Fig. 3 Semithin sections of the epithelium of seminiferous tubules of control and mutant mice stained with toluidine blue and immunohistochemistry of c-kit. a WT mice show coarse chromatin particles in spermatogonia (SG). Meiotic figures can be seen in primary spermatocytes (SC1). b WT show spermatids detached from the apical borders of Sertoli cells, leaving residual lobes (arrowhead). c WT mice show mature sperms (arrowheads) release with their flagella into the lumen of seminiferous tubules. $\mathbf{d}$ The mutant mice were characterized by changes in germ cells appearance and presence of mast cells (arrowheads) localized near the basement membrane among the primary spermatocytes (SC1). e The mutant mice exhibited signs of delay spermiation in form of retention of numerous spermatids deeper in the epithelium (arrowheads). f The mutant mice show irregularities in the basement membrane (BM) of seminiferous tubules and changes in sperm morphology (arrowheads). g Mast cell (arrowhead) in the interstitial tissue of the mutant mice.

$\mathbf{h}, \mathbf{i}$ The mutant mice expressed positive c-kit mast cells (arrowheads)
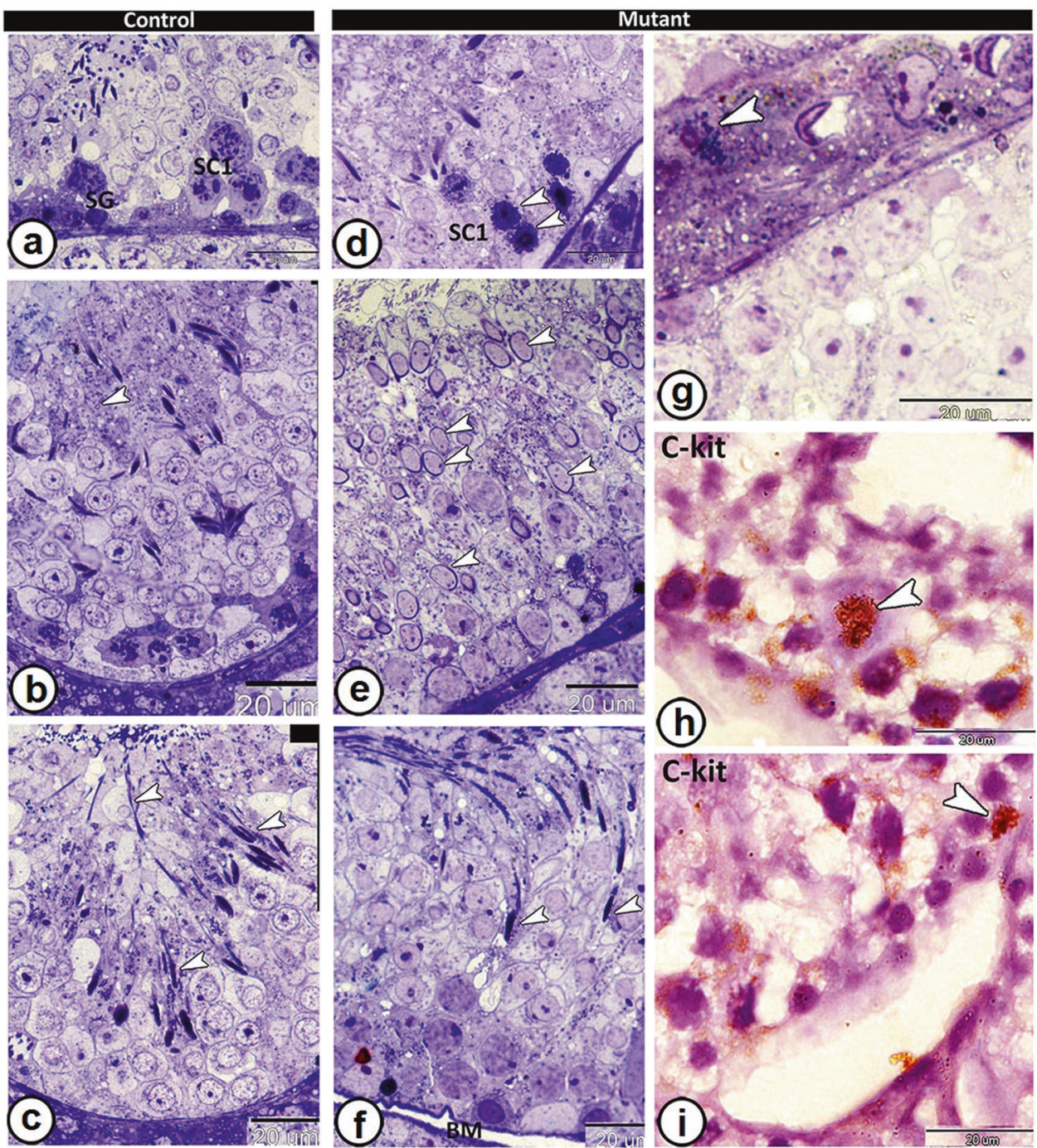

cells, were observed (Fig. 6d). VEGF immunopositivity was demonstrated in spermatocytes and round-spermatids of WT mice (Fig. 6e, g), while overexpression of VEGF was observed in seminiferous tubules of mutant mice (Fig. 6f, h).

Caspase- 3 showed a weak reaction in the interstitial tissues, with a normal pattern of apoptosis in the seminiferous tubules of WT (Fig. 7a), while increased caspase-3 expression was observed in all seminiferous tubules and interstitial tissues of mutant mice (Fig. 7b). The immunofluorescent stain in WT mice showed normal spermatogenic activity with the immunofluorescence localized in the developing spermatids (Fig. 7c). Fragmentations, condensation, and hyperchromatasia of the nucleus of the spermatogenic cells and an evident degree of apoptosis were clear in the mutant mice, especially at the basal borders of the seminiferous tubules that may be apoptotic spermatogonia and spermatocytes. Fragmentations in the nuclei of the interstitial cells were also frequent (Fig. 7d).

\section{Ultrastructural testicular changes of RORa-deficient mice}

In the WT mice, normal spermatogenesis was evident. Sertoli cells appeared as elongated cells with a large oval euchromatic nucleus, contained distinct nucleoli. Their cytoplasm displayed numerous mitochondria, lipid droplets and the developing spermatids were attached at their apical borders. Spermatogonia occupied the first two layers above the basement membrane. Spermatogonia were characterized by large euchromatic nucleus with many aggregations of heterochromatin (Fig. 8a). The cytoplasm of spermatogonia contained mitochondria with vesicular arranged cristae, Golgi apparatus, many profiles of rough endoplasmic reticulum (rER), and ribosomes (Fig. 8b).

In the mutant ROR $\alpha$-deficient mice, the seminiferous tubules showed thick basal lamina, abnormal Sertoli cells with residual bodies and small vacuoles, and retraction of the cytoplasm of Sertoli cells away from spermatids. 
Fig. 4 Semithin sections of the interstitial tissues of control and mutant mice stained with toluidine blue. a WT mice show seminiferous tubules (ST) surrounded by myoid cells (arrowheads). The interstitial tissue was composed of Leydig cells (LC), lymphocytes (L), and macrophages (M). b, c Telocytes (arrowheads) were spindleshaped dark cells distributed around the tubules and blood vessels. d, e The interstitial tissues of mutant mice show many lymphatic spaces (arrowhead), Leydig cells (LC) with many vacuoles and lipid droplets and fibroblasts $(\mathrm{F})$. f The mutant mice show few telocytes (arrowhead) and pale large macrophages (asterisk) with many metachromatic inclusions and large vacuole

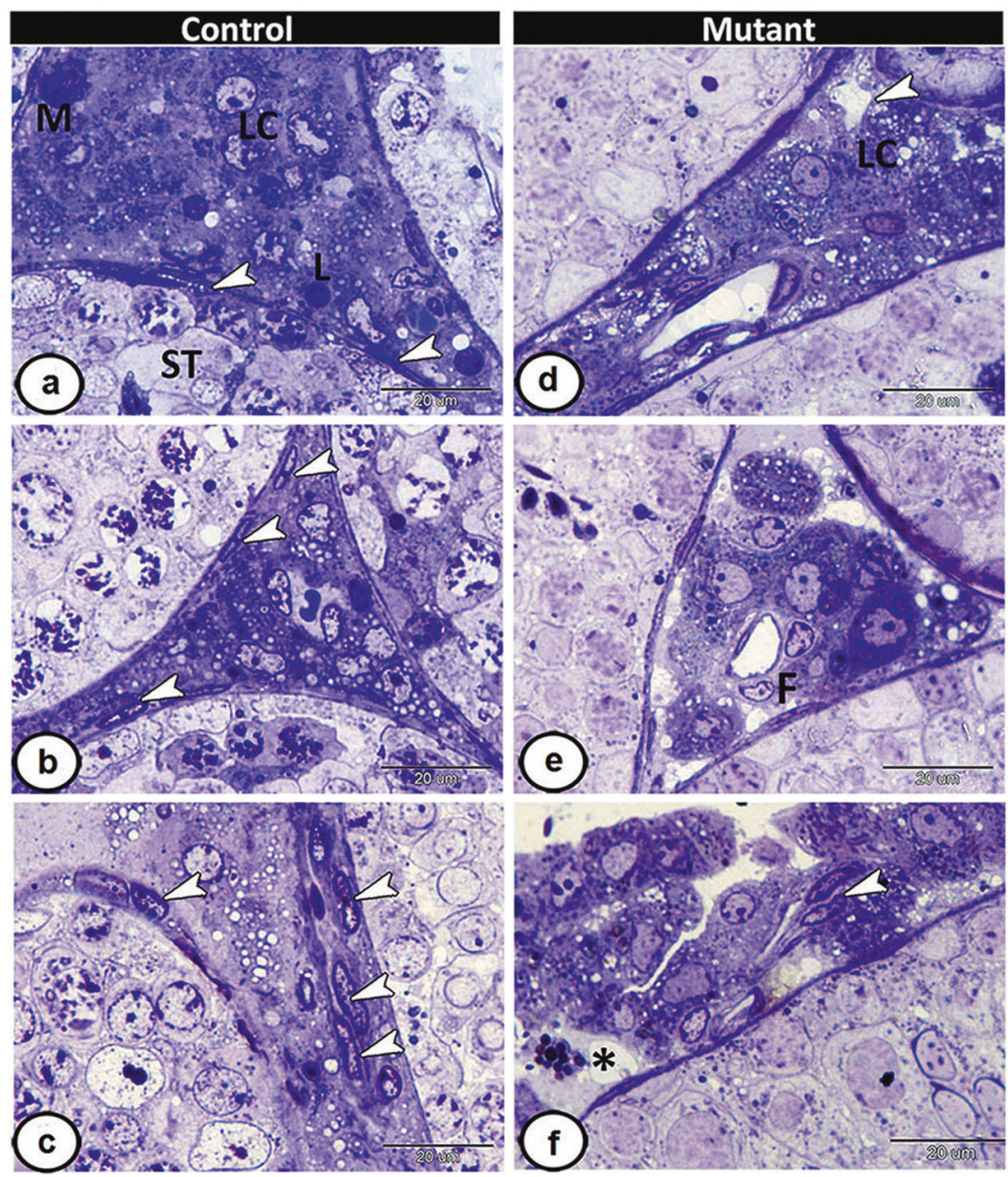

Interdigitations and irregularities of spermatogenic cells membranes were encountered. Spermatogonia occupied the first layer of the seminiferous tubules and contained vacuoles (Fig. 8c). Moreover, spermatogonia showed hypertrophy, large nucleus with few heterochromatin aggregations, and few cytoplasmic degenerated mitochondria (Fig. 8d).

The spermatocytes of the control mice were characterized by large rounded euchromatic nucleus, and their cytoplasm possessed mitochondria and rER (Fig. 9a). The cytoplasm of the spermatid was characterized by welldeveloped Golgi apparatus, mitochondria, and prominent acrosomal cap (Fig. 9b). Developing spermatids in the final acrosomal phase were also demonstrated in WT mice that display elongated shape, conical electron-dense nucleus with few cytoplasmic residues and developing flagellar axoneme (Fig. 9c). On the other hand, the spermatocytes of the mutant mice displayed heterochromatic nucleus and showed degenerated mitochondria, rER, many lysosomes, and deposition of some lipid droplets (Fig. 9d). The elongated spermatids were at the early acrosomal phase and they were displayed Golgi zone, mitochondria, and acrosomal cap over the nucleus that appeared elongated, condensed, and migrated towards the periphery of the cell (Fig. 9e) Incompletely developed-sperms were deeply observed in the epithelium of the mutant mice with massive cytoplasmic residues (Fig. 9f).

In the WT mice, Leydig cell cytoplasm contained many large mitochondria, $\mathrm{rER}$, few lysosomes, lipid droplets, and smooth endoplasmic reticulum (sER) arranged in both tightly packed tubular pattern and spiral-like concentric membranous profiles. The nucleus was ovoid in shape and may be with corrugated nuclear membrane and showed peripherally arranged clumps of heterochromatin. The TCs were distributed around the seminiferous tubules. They were elongated cells with cell bodies and cell processes (telopodes). The cell bodies contained oval euchromatic nucleus with peripherally arranged heterochromatin (Fig. 10a, b). The telopodes contained rER, mitochondria, and many secretory vesicles (Fig. 10c).

In the mutant mice, Leydig cells possessed irregular nuclear membrane and their cytoplasm contained many primary lysosomes, lipid droplets, vacuoles of different size, sER arranged in spiral-like concentric membranous profiles 
Fig. 5 The histochemical analysis and enzyme histochemistry of the testis of control and mutant mice. a WT mice show Leydig cells (LC), basement membrane (BM) of seminiferous tubules, and elongated spermatids (arrowhead) displayed PASpositive reaction. b Mutant testis show increase PAS-reaction in tubules and Leydig cells (LC), and appearance of symplasts (arrowhead). c In WT mice, the Leydig cells show strong reaction to bromophenol blue (arrowheads). d In mutant mice, the Leydig cells (LC) displayed a weak positive reaction, with many multinucleated giant bromophenol-positive cells (arrowheads). e WT mice show high ATPase activity in the form of dark brown color in all spermatogenic cells (boxed areas), and a strong staining pattern was localized in the apical borders of Sertoli cells with their associated elongated spermatids (arrowhead). f In mutant mice, the ATPase activity was limited to spermatogonia and some primary spermatocytes (boxed areas) and a weak reaction was detected in developing spermatids (arrowhead). $\mathbf{g}, \mathbf{h}$ The expression of alkaline phosphatase (boxed areas) was stronger in mutant mice compared with the WT mice
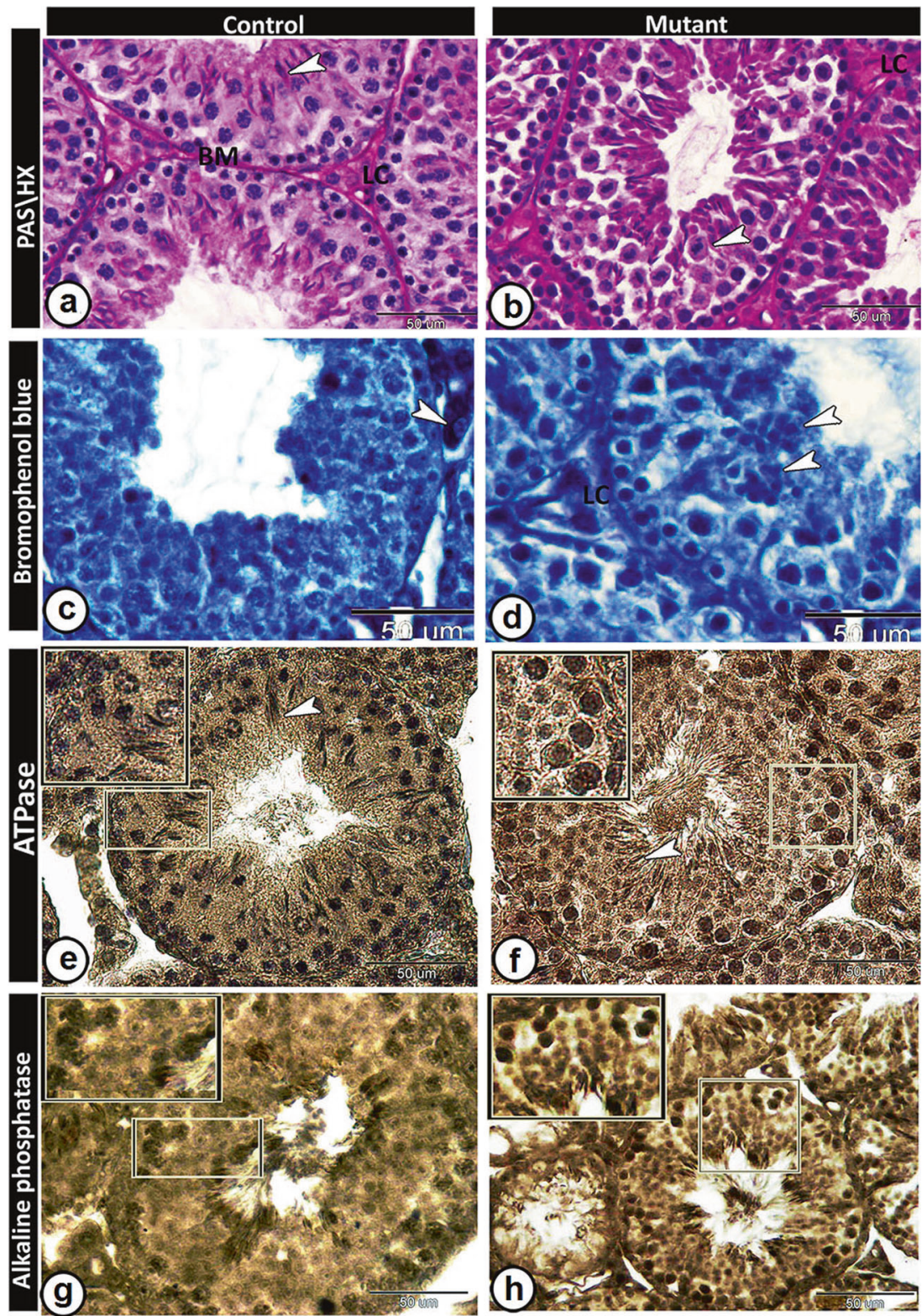

and degenerated mitochondria (Fig. 10d, e). Fibroblasts were observed between the Leydig cells and TCs, they were characterized by large oval euchromatic nucleus and rich rER cytoplasm (Fig. 10d). Macrophages with many electron-dense lysosomes were the characteristic feature of interstitial tissues of mutant mice (Fig. 10d). Dendritic reticular cell (natural killer cell) was demonstrated around the lymphatic vessels. It displayed large heterochromatic nucleus with cytoplasmic processes and its cytoplasmcontained mitochondria and rER (Fig. 10f). TCs were distributed around the blood capillaries and lymphatic vessels and established close contact with fibroblasts and dendritic reticular cells, and stromal synapse with macrophages. In addition, telopodes of one TC established direct contact with telopodes of anther TC. Although, their number was decreased and their telopodes were reduced in length and activity, as no secretory vesicles were observed in the TCs of mutant mice (Fig. 10d, f and Table 1).

\section{Discussion}

This is the first study detecting the role of ROR $\alpha$ expression in testicular architecture and spermatogenesis. A number of factors have been demonstrated to cause hypospermatogenesis, including hormone deficiency, genetic mutation, and environmental factors $[32,33]$. Genes are essential for spermatogenesis through participation in many cellular processes, including DNA repair [34], transcriptional control [35], and cell proliferation [36]. ROR nuclear orphan 
Fig. 6 Immunohistochemistry of the testis of control and mutant mice. a CD117 expression was strong in spermatogonia (boxed areas) and interstitial cells (arrowhead) in WT mice. b CD117 expression was limited to spermatogonia, and primary spermatocytes (boxed areas) and was weak in Leydig cells (arrowhead) of mutant mice. c WT mice show immunolocalized vimentin to the cytoplasm of spermatogonia, elongated spermatids (boxed areas), and Leydig cells (arrowhead). d In mutant mice, strong vimentin reaction was observed in the cytoplasm of spermatogonia, elongated spermatids (boxed areas), Leydig cells (arrowheads), and strong staining pattern was observed in Sertoli cells (S).

e, $\mathbf{g}$ WT mice showed immunolocalized VEGF (arrowhead) in spermatocytes (SC), and round spermatid (Sd)

f, $\mathbf{h}$ In mutant mice,

overexpression of VEGF

(arrowhead) in spermatocytes (SC), and round spermatid (Sd) was demonstrated
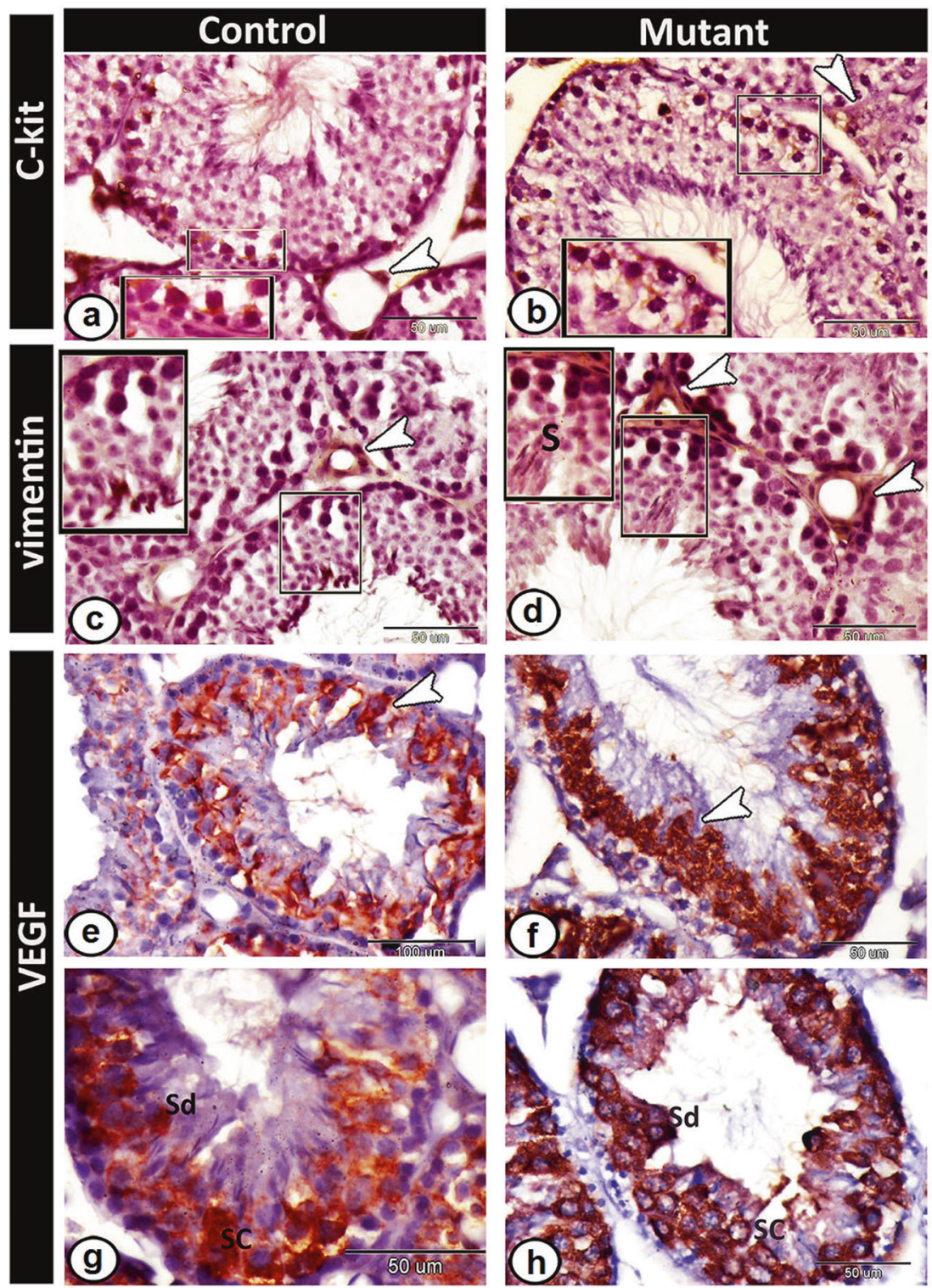

receptors family are definitive transcription factors, which is detected to play pivotal role in various biochemical processes such as inflammation [37], and lipid homeostasis [38]. ROR $\alpha$ is involved in tissue development and cellular function, including metabolism, and differentiation [39, 40]. In the spermatogonial stem cell differentiation culture system, $\mathrm{ROR} \alpha$ revealed a crucial role in stimulating melatoninregulated GATA-4 transcription and steroid hormone synthesis [13].

ROR $\alpha$ expression was previously observed in the testicular peritubular cells only after sexual maturation and also in the epididymal epithelial cells before puberty [41]. However, the knockout mice revealed no abnormal phenotype and the animals produced spermatocytes [42]. In the central nervous system, the expression of ROR $\alpha$ was detected in the suprachiasmatic nuclei, cerebellar Purkinje cells, thalamus, and retinal ganglion cells. Cerebellar and behavioral phenotype analysis of $\mathrm{ROR}^{-/-}$mice was similar to that of the ataxic staggerer $(\mathrm{sg} / \mathrm{sg}$ ) mutant mice [41], as both mice display equilibrium deficits, motor coordination, small size and die between 3-4 weeks of age [42, 43], as well as arrhythmic feeding behavior [44], with no apparent morphological effect on thalamus, and retina. Moreover, ROR $\alpha$ is expressed in the skin especially in hair follicles, epidermal keratinocytes, dermal fibroblasts, melanocytes, and sebaceous glands of the skin. Liver, pancreas, islet cells, adipose tissue, and the pineal gland were reported as sites for ROR $\alpha$ expression [41, 45].

Spermatogenic epithelial vacuolation was a common feature of the testis in the mutant group. This vacuolation may be associated with abnormal gene expression [46, 47], and it has been reported to play a role in sperms 
Fig. 7 Immunohistochemical and immunofluorescence detection of the apoptotic nuclei in the testis of control and mutant mice. a Caspase-3 showed weak reaction in interstitial tissues (arrowhead) in WT mice. b Massive number of brown-stained apoptotic cells (arrowheads) was observed in all seminiferous tubules and interstitial tissues of mutant mice. c Occasional apoptotic cells (boxed areas) present in WT mice, especially in the developing spermatids (arrowhead). d The majority of germ cells from mutant mice are undergoing apoptosis (boxed areas). Note: fragmentation of the nuclei of Leydig cells (arrow)
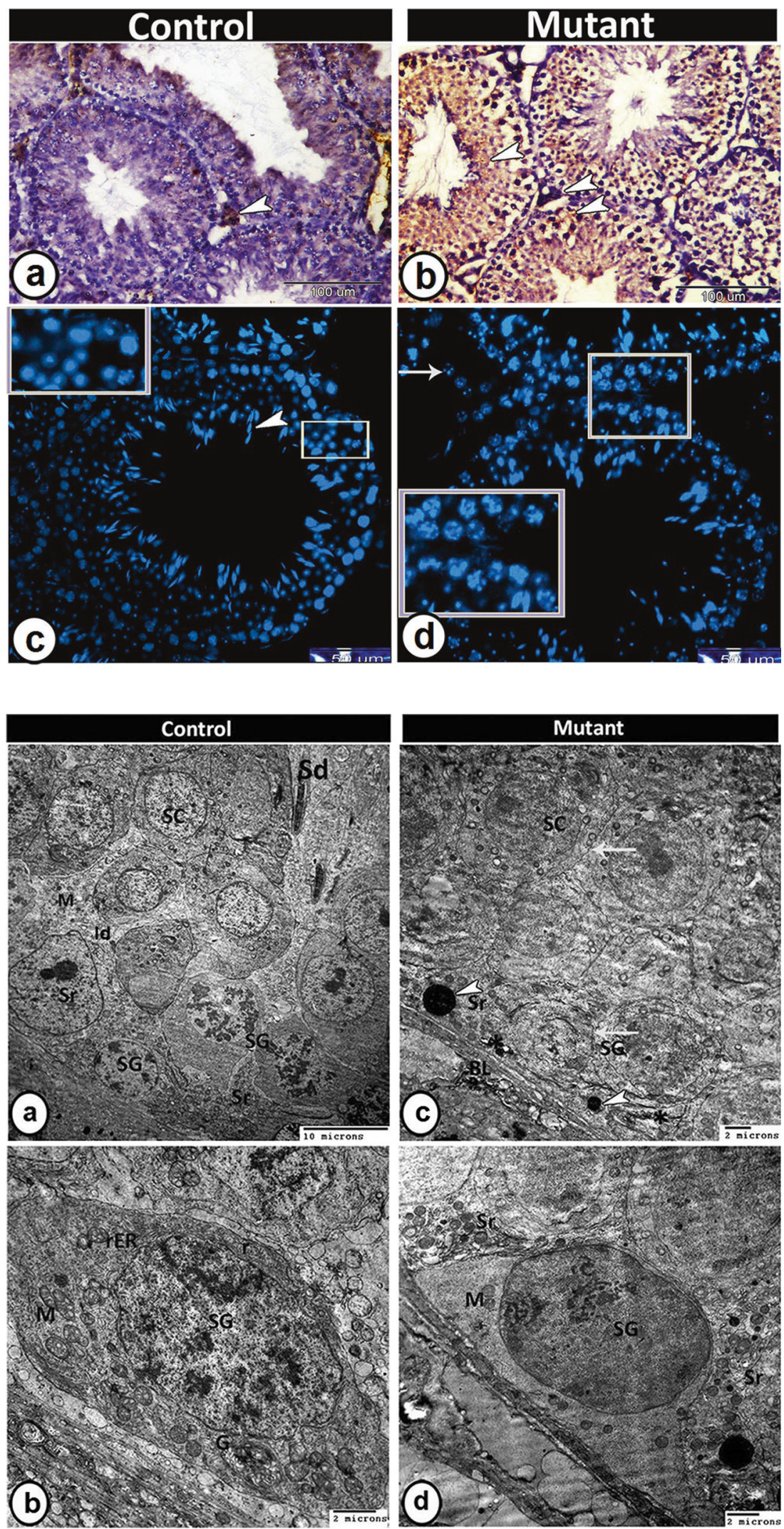
Fig. 9 Digital colored TEM of the seminiferous tubules of both control and mutant mice. a WT mice, with the spermatocytes (SC) contained mitochondria (M) and rough endoplasmic reticulum (rER). b The cytoplasm of the spermatids ( $\mathrm{Sd}$ ) in WT mice is characterized by

Golgi apparatus (G),

mitochondria $(\mathrm{M})$, and prominent acrosomal cap (arrowheads). c Developing spermatids (blue) in WT mice displayed conical electron-dense nucleus with few cytoplasmic residues and developing flagellar axoneme. $\mathbf{d}$ The spermatocytes (SC) of mutant mice display degenerated mitochondria $(\mathrm{M})$, rER, many lysosomes (L), and lipid droplets (ld). e In mutant mice, the spermatids ( $\mathrm{Sd}$ ) displayed Golgi zone (G), mitochondria $(\mathrm{M})$, and acrosomal cap (arrowhead) over the nucleus. f Incompletely developed sperms (blue) in mutant mice contained massive cytoplasmic residues
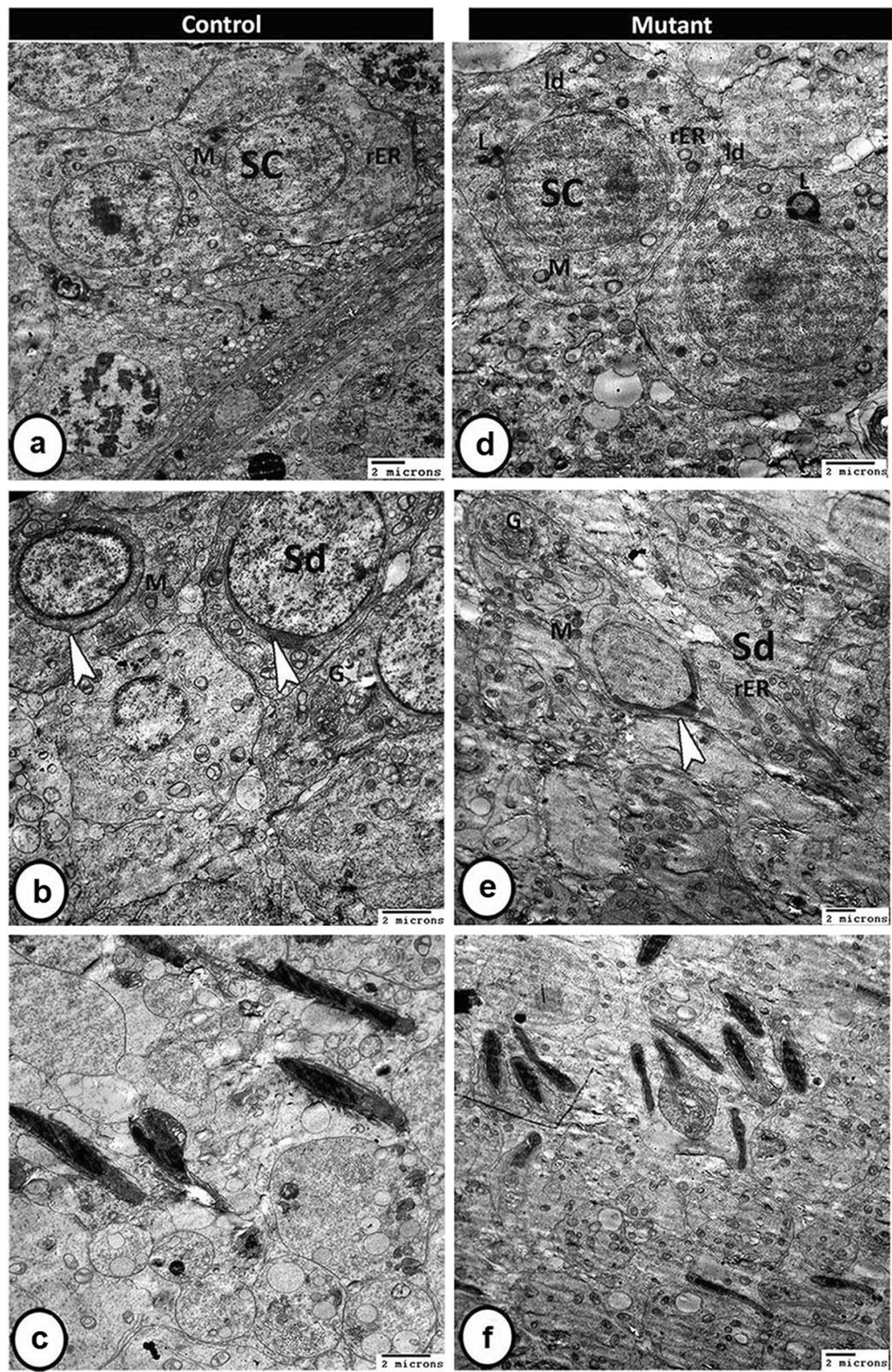

number decrease [48]. Moreover, seminiferous epithelial vacuolation indicates a breakdown in Sertoli-germ cell junctions [49].

Abnormalities in spermatogenesis induce germ cell apoptosis, which leads to the spermatogenetic arrest that causes subfertility or infertility [50]. The process of apoptosis has an important role in the testis throughout regulation of the number and quality of spermatogenic cells. We demonstrated the testicular germ cell death pattern in both control and mutant group. Excessive numbers of apoptotic cells were demonstrated by caspase- 3 and Hoechst stains in mutant mice indicating that $\mathrm{ROR} \alpha$ genes deletion prevents or reduces the differentiation of spermatogenic cells and induces apoptosis.

The occurrence of multinucleated giant cells in seminiferous tubules are represented a specific form of degenerating germ cell. This occurs because of the connection of the normal germ cells to each other during the division by cytoplasmic bridges. During some forms of degeneration, these cytoplasmic bridges can open and allow fusion of the cellular contents of the conjoined cells [51]. The seminiferous tubules of ROR $\alpha$-deficient mice demonstrated decreased diameter and height of their epithelium, with accumulation of degenerated spermatocytes in their lumen. 
Fig. 10 Digital colored TEM of the interstitial tissue of both control and mutant mice. a WT mice showing interstitial cell cytoplasm (IC) contained smooth endoplasmic reticulum (sER), mitochondria (M), lysosomes (L), and lipid droplets (lds). The telocytes (TCs) consisted of cell bodies and telopodes (Tps), which contained rough endoplasmic reticulum (rER), mitochondria (M), and many secretory vesicles (arrowheads). b Interstitial cell cytoplasm (IC) of WT mice demonstrating peripherally arranged clumps of heterochromatin. c Telocyte (TC) of WT mice revealing many secretory vesicles (arrowheads). d, e Mutant mice showing interstitial cells (IC) contained many lysosomes (L), lipid droplets (lds), many vacuoles $(\mathrm{V}), \mathrm{sER}$, and degenerated mitochondria (M). Note: Fibroblasts (F), and Macrophages (MA) with many electron-dense lysosomes. Telocytes (TCs) were distributed around the blood capillaries (BC). f Dendritic reticular cell (DC) was demonstrated around the lymphatic vessels (LV) in the mutant mice. Telocytes (TCs) were distributed around the lymphatic vessels (LV). Note: telopodes (Tps) of adjacent TCs were connected together
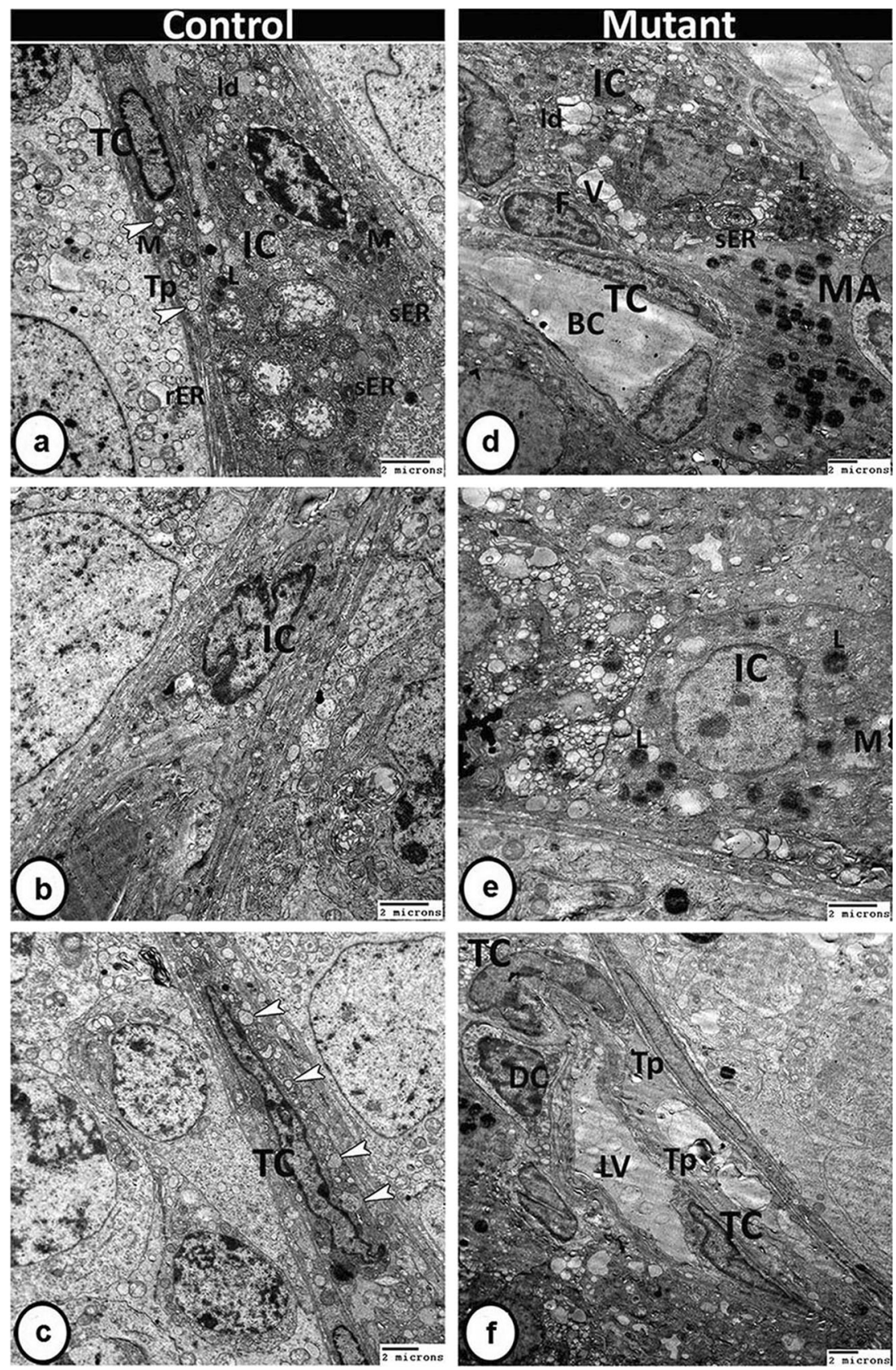

The tubules diameter was previously reported to be reduced in ROR $\alpha$-knockdown rats, and clumps of unreleased sperm were detectable in the lumen [12].

In the current study, abnormal Sertoli cells were demonstrated to engulf the heads of spermatids in the mutant group and their cytoplasm contained many residual bodies and small vacuoles. Sertoli cells are phagocytic cells, whereby their lysosomes are involved in the degradation of the excess cytoplasm or residual bodies emanating from late spermatids at the time of spermiation [52]. The inability of Sertoli cells to support spermatogenesis is one major category of male infertility and reduced sperm count [53], as these cells govern the differentiation process of spermatogonial stem cells into mature sperms through providing many factors necessary for spermatogenesis through the action of testosterone and FSH [54]. The previous study revealed the predominant presence of binding sites of $\mathrm{ROR} \alpha$ in the nucleus of pubertal Sertoli cells, suggesting that ROR $\alpha$ play a role in the functioning of these pubertal cells to support spermatogenesis. Furthermore, Sertoli cells knockdown of ROR $\alpha$ receptors at puberty reduces sperm count $[12,55]$. So, our findings confirmed the importance of ROR $\alpha$ for normal spermatogenesis and Sertoli cells function. 
ATP is known to play a key role in storage and utilization of metabolic energy in most of mammalian tissues including testis. High ATPase activity was detected in spermatogonia of control mice that may be related to a high energy required for an active germ cells proliferation and differentiation. High ATPase was also concentrated in elongated spermatids as they contained a large number of mitochondria, which act as an evident factor of energy supply for sperm motility. In mutant mice, the alkaline phosphatase activity was higher, as it is well-known that tissue damage can promote an increase of the intensity of alkaline phosphatase activity [56]. Also, mitochondrial damage or degeneration can induce alkaline phosphatase staining increase.

Variations in intensity and patterns of staining of intermediate filaments like vimentin between control and mutant testis may reflect the testicular degree of degeneration. Our results reported intense vimentin expression in testis of mutant mice that corresponded with studies on human testes with varicocele and in monkey testes with cryptorchidism $[57,58]$, and may this act as a complementary mechanism to retain the testis function. However, the biological role of vimentin filaments in Sertoli cells and in other cell types has not been fully elucidated. It has been assumed that intermediate filaments provide mechanical support and strength to cells [59]. Moreover, vimentin filaments are known to be involved in maintaining the integrity of Sertoli cells to adjacent spermatogenic cell contacts, in anchoring germ cells to the seminiferous tubules. So, they play a crucial role in spermatogenesis [60]. CD117 is a cytokine receptor that expresses on stem cells and other cell types. Altered forms of this receptor may be associated with some types of cancer or gene mutations [61].

VEGF is a peptide essential for angiogenesis and targets nonvascular cells in a variety of tissues. It was expressed in testicular germ cells of mice [62] and showed immunopositivity in spermatocytes and spermatids [63]. The present study demonstrated overexpression of VEGF in seminiferous tubules of mutant mice. Overexpression of VEGF in testis was reported to be associated with infertility [64]. The precise role of VEGF in testis remains unclear, however, it was suggested that VEGF may regulate germ cell proliferation and create a suitable niche for spermatogenesis in bovine testis [65].

The reason for the increased frequency of macrophages in ROR $\alpha$-deficient mice is not totally resolved. Macrophages are involved in the removal of cellular debris and dead cells [66]. In addition, macrophages secrete 25hydroxycholesterol, a lipophilic factor, which induces Leydig cells to produce testosterone [67].

Based on TCs morphology and distribution, the present study reported close contact of TCs with dendritic reticular cells and stromal synapse with macrophage in the interstitial tissues, which may indicate the involvement of these cells in the immune response. TCs act as a primitive nervous system for the cells found in close relation with it and even for those found at a distance [68]. The later authors also claim that TCs are well-equipped cells (concerning different types of junctions), which play a role in the information pathway, and that may be detected in the present study through their junction with fibroblasts. TCs were shown to join stem cells in the regeneration and repair from myocardial infarction [69]. Recently, there is increasing evidence that TCs can be a therapeutic target in regenerative medicine [70].

In conclusion, we provided here fundamental evidence suggesting that $\operatorname{ROR} \alpha$ transcription factor is one of the essential proteins that regulate both qualitative and quantitative testicular structure and, so, spermiogenesis, which may be significantly affected by any defect in $\operatorname{ROR} \alpha$ expression. The lack of $\operatorname{ROR} \alpha$ expression induces apoptosis, reduces the germ cells differentiation, and may cause infertility. The enzymatic activity gave an insight into the testicular disturbance. ROR $\alpha$-deficient mice may act as models for the demonstration of mutation-induced changes in many characters of human infertility. Further postnatal developmental studies on the testicular structure in young and old WT and KO mice should be done to get better insights on the role of $\operatorname{ROR} \alpha$ and progression of its phenotype, and also to correlate the testicular changes with those in other reproductive organs of mutant mice, including the epididymis, prostate, seminal vesicles, and urethral anatomy.

Acknowledgements This study has been funded by Instituto de Salud Carlos III through the projects RD12/0043/0005, PI13-00981, PI1600519, and CB/10/00238 (Co-funded by European Regional Development Fund/European Social Fund) "Investing in your future"); the Consejería de Economía, Innovación, Ciencia y Empleo, Junta de Andalucía, Spain (CTS-101), and also by Assiut and Sohag Universities, Egypt. MF-O is supported by FPU grant from the Ministerio de Educación, Cultura y Deporte, Spain. We are thankful to members of Electron Microscopy Unit (Assiut University, Egypt) for their technical support with transmission electron microscopy.

\section{Compliance with ethical standards}

Conflict of interest The authors declare that they have no conflict of interest.

Publisher's note: Springer Nature remains neutral with regard to jurisdictional claims in published maps and institutional affiliations.

\section{References}

1. He YW, Deftos ML, Ojala EW, et al. RORgamma t, a novel isoform of an orphan receptor, negatively regulates Fas ligand expression and IL-2 production in T cells. Immunity. 1998; 9:797-806. 
2. Jetten AM, Joo JH. Retinoid-related orphan receptors (RORs): roles in cellular differentiation and development. Adv Dev Biol. 2006;16:313-55.

3. Carlberg C, Hooft van Huijsduijnen R, Staple JK, et al. RZRs, a new family of retinoid-related orphan receptors that function as both monomers and homodimers. Mol Endocrinol. 1994;8:757-70.

4. Jetten AM, Kurebayashi S, Ueda E. The ROR nuclear orphan receptor subfamily:critical regulators of multiple biological processes. Prog Nucleic Acid Res Mol Biol. 2001;69:205-47.

5. André E, Conquet F, Steinmayr M, et al. Disruption of retinoidrelated orphan receptor $\beta$ changes circadian behavior, causes retinal degeneration and leads to vacillans phenotype in mice. EMBO J. 1998;17:3867-77.

6. Delerive P, Monté D, Dubois G, et al. The orphan nuclear receptor ROR alpha is a negative regulator of the inflammatory response. EMBO Rep. 2001;2:42-8.

7. Lau P, Nixon SJ, Parton RG, et al. RORalpha regulates the expression of genes involved in lipid homeostasis in skeletal muscle cells: caveolin-3 and CPT-1 are direct targets of ROR. J Biol Chem. 2004;279:36828-40.

8. Akashi M, Takumi T. The orphan nuclear receptor RORalpha regulates circadian transcription of the mammalian core-clock Bmal1. Nat Struct Mol Biol. 2005;12:441-8.

9. Jetten AM. Retinoid-related orphan receptors (RORs): critical roles in development, immunity, circadian rhythm, and cellular metabolism. Nucl Recept Signal. 2009;7:942-9.

10. García JA, Volt H, Venegas C, et al. Disruption of the NF-kB/ NLRP3 connection by melatonin requires retinoid-related orphan receptor- $\alpha$ and blocks the septic response in mice. FASEB J. 2015;29:3863-75.

11. Zhang Y, Luo X, Wu D, et al. ROR nuclear receptors: structures, related diseases, and drug discovery. Acta Pharmacol Sin. 2015;36:71-87.

12. Mandal K, Sarkar RK, Sharma SS, et al. Sertoli cell specific knockdown of RAR-related orphan receptor (ROR) alpha at puberty reduces sperm count in rats. Gene. 2018;641:18-24.

13. Deng SL, Zhang Y, Yu K, et al. Melatonin up-regulates the expression of the GATA-4 transcription factor and increases testosterone secretion from Leydig cells through ROR $\alpha$ signaling in an in vitro goat spermatogonial stem cell differentiation culture system. Oncotarget. 2017;8:110592-605.

14. Deng SL, Wang ZP, Jin C, et al. Melatonin promotes sheep Leydig cell testosterone secretion in a co-culture with Sertoli cells. Theriogenology. 2018;106:170-7.

15. Siu MK, Cheng CY. Dynamic cross-talk between cells and the extracellular matrix in the testis. Bioessays. 2004;26:978-92.

16. Griswold MD. The central role of Sertoli cells in spermatogenesis. Semin Cell Dev Biol. 1998;9:411-6.

17. Ge R, Chen G, Hardy MP The role of the Leydig cell in spermatogenic function. In: Cheng CY editor. Molecular mechanisms in spermatogenesis. Advances in experimental medicine and biology. New York, NY: Springer; 2009. 255-69.

18. Popescu LM, Faussone-Pellegrini MS. Telocytes: a case of serendipity: the winding way from interstitial cells of Cajal (ICC), via interstitial Cajal-like cells (ICLC) to telocytes. J Cell Mol Med. 2010;14:729-40.

19. Burton LD, Housley GD, Salih SG, et al. P2X2 receptor expression by interstitial cells of Cajal in vas deferens implicated in semen emission. Auton Neurosci. 2000;84:147-61.

20. Exintaris B, Klemm MF, Lang RJ. Spontaneous slow wave and contractile activity of the guinea pig prostate. J Urol. 2002;168:315-22.

21. Mokhtar DM, Abd-Elhafeez HH, Abou-Elmagd A, et al. Melatonin administration induced reactivation in the seminal gland of the soay rams during non-breeding season: an ultrastructural and morphometrical study. J Morphol. 2016;277:231-43.
22. Hamilton BA, Frankel WN, Kerrebrock AW, et al. Disruption of the nuclear hormone receptor RORa in staggerer mice. Nature. 1996:379:736-9.

23. Harris HF. On the rapid conversion of haematoxylin into haematin in staining reactions. In: Bancroft JD, Steven A. Theory and practice of histological techniques. 4th ed. New York: Churchill Livingstone; 1996.

24. Crossmon G. A modification of Mallory's connective tissue stain with discussion of the principle involved. Anat Rec. 1937;69:33-8.

25. McManus JF. Histological demonstration of mucin after periodic acid. Nature. 1946;158:202.

26. Pearse AG. Histochemical: theoretical and applied. London: Churchill; 1985.

27. Bancroft JD, Gamble M. Theory and practice of histological and histochemical techniques, 3rd ed. Butter Worths; 2002.

28. Gomori G. Histochemistry of estrases. Int Rev Cytol. 1952;1:323-35.

29. Latt SA, Stetten G, Juergens LA, et al. Recent developments in the detection of deoxyribonucleic acid synthesis by 33258 Hoechst fluorescence. J Histochem Cytochem. 1975;23:493-505.

30. Karnovsky MJ. A formaldehyde-glutraldehyde fixative of high osmolarity for use in electron microscopy. J Cell Biol. 1965;27:137-138A.

31. Reynolds ES. The use of lead citrate at high $\mathrm{pH}$ as an electronopaque stain in electron microscopy. J Cell Biol. 1963;17:208-12.

32. Toshimori $\mathrm{K}$, Ito $\mathrm{C}$, Maekawa $\mathrm{M}$, et al. Impairment of spermatogenesis leading to infertility. Anat Sci Int. 2004;79:101-111.

33. Carrell DT, De Jonge C, Lamb D. The genetics of male infertility: a field of study whose time is now. Arch Androl. 2006;52:269-74.

34. Baker SM, Bronner CE, Zhang L, et al. Male mice defective in the DNA mismatch repair gene PMS2 exhibit abnormal chromosome synapsis in meiosis. Cell. 1995;82:309-19.

35. Blendy JA, Kaestner KH, Weinbauer GF, et al. Severe impairment of spermatogenesis in mice lacking the CREM gene. Nature. 1996;380:162-5.

36. Toscani A, Mettus RV, Coupland R, et al. Arrest of spermatogenesis and defective breast development in mice lacking A-myb. Nature. 1997;386:713-7.

37. Jaradat M, Stapleton C, Tilley SL, et al. Modulatory role for retinoid-related orphan receptor alpha in allergen-induced lung inflammation. Am J Respir Crit Care Med. 2006;174:1299-309.

38. Fitzsimmons RL, Lau P, Muscat GE. Retinoid-related orphan receptor alphaand the regulation of lipid homeostasis. J Steroid Biochem Mol Biol. 2012;130:159-68.

39. Ohoka N, Kato S, Takahashi Y, et al. The orphan nuclear receptor $\mathrm{ROR} \alpha$ restrains adipocyte differentiation through a reduction of $\mathrm{C} /$ EBP $\beta$ ACtivity and Perilipin Gene Expression. Mol Endocrinol. 2009;23:759-71.

40. Kojima H, Muromoto R, Takahashi M, et al. Inhibitory effects of azole-type fungicides on interleukin-17 gene expression via retinoic acid receptor-related orphan receptors $\alpha$ and $\gamma$. Toxicol Appl Pharmacol. 2012;259:338-45.

41. Steinmayr M, André E, Conquet F, et al. Staggerer phenotype in retinoid-related orphan receptor alpha-deficient mice. Proc Natl Acad Sci USA. 1998;95:3960-5.

42. Guastavino JM. Environmental features determining successful rearing in the mutant mouse staggerer. Physiol Behav. 1984;32: $225-8$.

43. Dussault I, Fawcett D, Matthyssen A, et al. Orphan nuclear receptor ROR alpha-deficient mice display the cerebellar defects of staggerer. Mech Dev. 1998;70:147-53.

44. Guastavino JM, Bertin R, Portet R. Effects of the rearing temperature on the temporal feeding pattern of the staggerer mutant mouse. Physiol Behav. 1991;49:405-9.

45. Fan J, Lv Z1, Yang G, et al. Retinoic acid receptor-related orphan receptors: critical roles in tumorigenesis. Front Immunol. 2018; 9:1187. 
46. Chuma S, Hosokawa M, Kitamura K, et al. Tdrd1/Mtr-1, a tudorrelated gene, is essential for male germ-cell differentiation and nuage/germinal granule formation in mice. Proc Natl Acad Sci USA. 2006;103:15894-9.

47. Paiardi C, Pasini ME, Gioria M, et al. Failure of acrosome formation and globozoospermia in the wobbler mouse, a Vps54 spontaneous recessive mutant. Spermatogenesis. 2011;1:52-62.

48. Hentrich A, Wolter M, Szardening-Kirchner C, et al. Reduced numbers of Sertoli, germ, and spermatogonial stem cells in impaired spermatogenesis. Mod Pathol. 2011;24:1380-9.

49. Liao W, Cai M, Chen J, et al. Hypobaric hypoxia causes deleterious effects on spermatogenesis in rats. Reproduction. 2010;139:1031-8.

50. Shaha C, Tripathi R, Mishra DP. Male germ cell apoptosis: regulation and biology. Philos Trans R Soc Lond B Biol Sci. 2010;365:1501-15.

51. Creasy D, Bube A, de Rijk E, et al. Proliferative and non proliferative lesions of the rat and mouse male reproductive system. Toxicol Pathol. 2012;40:40S-121S.

52. Russell LD. Role in spermiation. In: Russell LD and Griswold MD editors. The Sertoli cell. Clearwater, FL: Cache River Press; 1993. 269-304.

53. Kanatsu-Shinohara $\mathrm{M}$, Miki $\mathrm{H}$, Inoue $\mathrm{K}$, Ogonuki $\mathrm{N}$, et al. Germline niche transplantation restores fertility in infertile mice. Hum Reprod. 2005;20:2376-82.

54. Walker WH. Testosterone signaling and the regulation of spermatogenesis. Spermatogenesis. 2011;1:116-20.

55. Mandal K, Bader SL, Kumar P, et al. An integrated transcriptomics-guided genome-wide promoter analysis and nextgeneration proteomics approach to mine factor(s) regulating cellular differentiation. DNA Res. 2017;24:143-57.

56. Ciplea AG, Metze K, Grundmann E, et al. Microphotometric quantitation of enzyme activities in giant cell tumor of bone. Pathol Res Pract. 1985;179:412-8.

57. Santamaría L, Martín R, Nistal M, et al. The peritubular myoid cells in the testes from men with varicocele: An ultrastructural, immunohistochemical and quantitative study. Histopathol. 1992; 21:423-33.

58. Zhang ZH, Hu ZY, Song XX, et al. Disrupted expression of intermediate filaments in the testes of rhesus monkey after experimental cryptorchidism. Int J Androl. 2004;27:234-9.
59. Fuchs E, Cleveland DW. A structural scaffolding of intermediate filaments in health and disease. Science. 1998;279:514-9.

60. Hejmej A, Kotula-Balak M, Sadowska J, et al. Expression of connexin 43 protein in testes, epididymides, and prostates of stallions. Equine Vet J. 2007;39:122-7.

61. Koshimizu U, Watanabe D, Tajima Y, et al. Effects of W (c-kit) gene mutation on gametogenesis in male mice: agametic tubular segments in Wf/ Wf testes. Development. 1992;114:861-7.

62. Nalbandian A, Dettin L, Dym M, et al. Expression of vascular endothelial growth factor receptors during male germ cell differentiation in the mouse. Biol Reprod. 2003;69: 985-94.

63. Seval-Celik Y, Akkoyunlu G, Kocamaz E, et al. Expression of vascular endothelial growth factor and transforming growth factor alpha in rat testis during chronic renal failure. Folia Histochem Cytobiol. 2014;52:308-16.

64. Korpelainen EI, Karkkainen MJ, Tenhunen A, et al. Overexpression of VEGF in testis and epididymis causes infertility in transgenic mice: evidence for nonendothelial targets for VEGF. J Cell Biol. 1998;143:1705-12.

65. Schmidt JA, de Avila JM, McLean DJ. Effect of vascular endothelial growth factor and testis tissue culture on spermatogenesis in bovine ectopic testis tissue xenografts. Biol Reprod. 2006;75: $167-75$.

66. Territo MC, Cline MJ. Mononuclear phagocyte proliferation, maturation, and function. Clin. Haematol. 1975;4:685-703.

67. Nes WD, Lukyanenko YO, Jia ZH, et al. Identification of the lipophilic factor produced by macrophages that stimulates steroidogenesis. Endocrinology. 2000;141:953-8.

68. Smythies J, Edelstein L. Telocytes, exosomes, gap junctions and the cytoskeleton: the makings of a primitive nervous system? Front Cell Neurosci. 2014;7:278.

69. Popescu LM, Gherghiceanu M, Manole CG, et al. Cardiac renewing: interstitial Cajal-like cells nurse cardiomyocyte progenitors in epicardial stem cell niches. J Cell Mol Med. 2009;13:866-86.

70. Mokhtar DM, Hussein MT, Hassan AH. Melatonin elicits stimulatory action on the adrenal gland of soay ram: Morphometrical, immunohistochemical, and ultrastructural study. Microsc Microanal. 2017;23:1173-88. 